\title{
TWELFTH ANNUAL LIST OF PAPERS
}

\author{
READ BEFORE THE AMERICAN MATHEMATICAL SOCIETY AND \\ SUBSEQUENTLY PUBLISHED, INCLUDING REFERENCES
}

TO THE PLACES OF THEIR PUBLICATION.

Allardice, R. E. On the Envelope of the Axes of a System of Conics Passing Through Three Fixed Points. Read (Chicago) Jan. 2, 1903. Transactions of the American Mathematical Society, vol. 4, No. 1, pp. 103-106; Jan., 1903.

BlichferdT, H. F. On the Determination of the Distance between Two Points in Space of $n$ Dimensions. Read (San Francisco) May 3, 1902. Transactions of the American Mathematical Society, vol. 3, No. 4, pp. 467-481; Oct., 1902.

- Note on a Property of the Conic Sections. Read (San Francisco) Dec. 20, 1902. Bulletin of the American Mathematical Society, vol. 9, No. 6, pp. 306-307; Mar., 1903.

Bliss, G. A. The Geodesic Lines on the Anchor Ring. Read (Chicago) Dec. 27, 1900. Annals of Mathematics, 2 d ser., vol. 4, No. 1, pp. 1-21; Oct., 1902.

Bôcher, M. On Systems of Linear Differential Equations of the First Order. Read Feb. 22, 1902. American Journal of Mathematics, vol. 24, No. 4, pp. 311-318; Oct., 1902.

Singular Points of Functions Which Satisfy Partial Differential Equations of the Elliptic Type. Read Dec. 30, 1902. Bulletin of the American Mathematical Society, vol. 9, No. 9, pp. 455-465; June, 1903.

BolzA, O. Some Instructive Examples in the Calculus of Variations. Read Sept. 2, 1902. Bulletin of the American Mathematical Society, vol. 9, No. 1, pp. 1-10; Oct., 1902.

Ueber das isoperimetrische Problem auf einer gegebenen Fläche. Read (Chicago) Mar. 29, 1902. Mathematische Annalen, vol. 57, No. 1, pp. 48-52; Mar., 1903. Also University of Chicago Decennial Publications, vol. 9, pp. 13-18.

Brown, E. W. On the Formation of the Derivatives of the Lunar Coordinates with Respect to the Elements. Read Feb. 28, 1903. Transactions of the American Mathematical Society, vol. 4, No. 3, pp. 234-248; July, 1903.

- On the Variation of the Arbitrary and Given Constants in Dynamical Equations. Read Apr. 25, 1903. Transactions of the American Mathematical Society, vol. 4, No. 3, pp. 333-350; July, 1903.

Coble, A. B. The Quartic Curve as Related to Conics. Read Dec. 27, 1901. Transactions of the American Mathematical Society, vol. 4, No. 1, pp. 65-85; Jan., 1903. 
Coolidge, J. L. Quadric Surfaces in Hyperbolic Space. Read Apr. 26, 1902. Transactions of the American Mathematical Society, vol. 4, No. 2, pp. 161-170; Apr., 1903.

Darws., G. H. The Approximate Determination of the Form of Maclaurin's Spheroid. Read Dec. 29, 1902. Transactions of the American Mathematical Society, vol. 4, No. 2, pp. 113-133; Apr., 1903.

Davis, E. W. Some Groups in Logic. Read (Chicago) Jan. 2, 1903. Bulletin of the American Mathematical Society, vol. 9, No. 7, pp. 346-348; Apr., 1903.

A Definition of Mathematical Probability. Read (Chicago) Apr. 6, 1901. Baldwin's Dictionary of Philosophy and Psychology, Article on Probability, vol. 2, pp. 344-353; 1902.

Drckson, L. E. Definitions of a Field by Independent Postulates. Read Sept. 2, 1902. Transactions of the American Mathematical Society, vol. 4, No. 1, pp. 13-20; Jan. 1903.

Definitions of a Linear Associative Algebra by Independent Postulates. Read Sept. 2, 1902. Transactions of the American Mathematical Society, vol. 4, No. 1, pp. 21-26; Jan., 1903.

Three Sets of Generational Relations Defining the Abstract Simple Group of Order 504. Read Oct. 25, 1902. Bulletin of the American Mathematical Society, vol. 9, No. 4, pp. 194-204; Jan., 1903.

Generational Relations Defining the Abstract Simple Group of Order 660. Read Oct. 25, 1902. Bulletin of the American Mathematical Society, vol. 9, No. 4, pp. 204-206; Jan, 1903.

The Abstract Group $G$ Simply Isomorphic with the Alternating Group on Six Letters. Read Dec. 29, 1902. Bulletin of the American Mathematical Society, vol. 9, No. 6, pp. 303-306; Mar., 1903.

Theorems on the Residues of Multinomial Coefficients with Respect to a Prime Modulus. Read (Chicago) Mar. 29, 1902. Quarterly Journal of Pure and Applied Mathematics, vol. 33, No. 4, pp. 378384; Apr., 1902.

The Group of the Equation for the Twenty-seven Lines on a General Cubic Surface. Read (Chicago) Dec. 28, 1900. Comptes Rendus, vol. 128, No. 14, pp. 873-5; Apr., 1899. Dickson's Linear Groups, pp. 303-7.

The Hyperorthogonal Groups. Read Apr. 27, 1901. Mathematische Annalen, vol. 55, No. 4, pp. 521-572; Feb., 1902.

The Group Defined for a General Field by the Rotation Groups. Read (Chicago) Jan. 2, 1903. University of Chicago Decennial Publications, vol. 9, pp. 36-51.

The Ternary Orthogonal Group in a General Field. Read (Chicago) Jan. 2, 1903. University of Chicago Decennial Publications, vol. 9 , pp. 28-34. 
Dunkel, O. Regular Singular Points of a System of Homogeneous Linear Differential Equations of the First Order. Read Sept. 2, 1902. Proceedings of the American Academy of Arts and Sciences, vol. 38, No. 9, pp. 341-370; Oct., 1902.

EIsenhart, L. P. Infinitesimal Deformation of the Skew Helicoid. Read Sept. 3, 1902. Bulletin of the American Mathematical Society, vol. 9, No. 3, pp. 148-152; Dec., 1902.

- Surfaces Referred to Their Lines of Length Zero. Read Oct. 25, 1902. Bulletin of the American Mathematical Society, vol. 9, No. 5, pp. 242-245; Feb., 1903.

Isothermal Conjugate Systems of Lines on Surfaces. Read Apr. 27, 1901. American Journal of Mathematics, vol. 25, No. 3, pp. 213-248; July, 1903.

EмcH, A. Algebraic Transformations of a Complex Variable Realized by Linkages. Read (Chicago) Jan. 2, 1902. Transactions of the American Mathematical Society, vol. 3, No. 4, pp. 493-498; Oct., 1902.

- A Linkage for $u=e^{\theta i i_{z}}$. Read Sept. 2, 1902. University of Colorodo Studies, vol. 1, No. 3, pp. 211-218; Jan., 1903.

Epsteen, S. On Integrability by Quadratures. Read Sept. 3, 1902. Bulletin of the American Mathematical Society, vol. 9, No. 3, pp. 152-154; Dec., 1902.

Determination of the Group of Rationality of a Linear Differential Equation. Read (Chicago) Jan. 2, 1903. American Mathematical Monthly, vol. 10, No. 1, pp. 4-8; Jan., 1903.

On Reducible Groups. Read (San Francisco) May 3, 1902. Transactions of the American Mathematical Society, vol. 4, No. 3, pp. 249-250; July, 1903.

Fields, J. C. Algebraic Proofs of the Riemann-Roch Theorem and of the Independence of the Conditions of Adjointness. Read (Chicago) Dec. 28, 1900. Acta Mathematica, vol. 26, No. 2, pp. 157-170; June, 1902.

Fite, W. B. Concerning the Commutator Subgroups of Groups whose Orders are Powers of Primes. Read Sept. 2, 1902. Bulletin of the American Mathematical Society, vol. 9, No. 3, pp. 139-141; Dec., 1902.

Fond, W. B. On the Possibility of Differentiating Term by Term the Developments for an Arbitrary Function of One Real Variable in Terms of Bessel Functions. Read Sept. 3, 1902. Transactions of the American Mathematical Society, vol. 4, No. 2, pp. 178-184; Apr., 1903.

GALE, A. S. On the Rank, Order and Class of Algebraic Minimum Curves. Read Feb. 22, 1902. Transactions of the American Mathematical Society, vol. 3, No. 4, pp. 45l-466; Oct., 1902.

On a Generalization of the Set of Associated Minimum Surfaces. Read Feb. 28, 1903. Annals of Mathematics, $2 \mathrm{~d}$ ser., vol. 4, No. 3, pp. 107-115; Apr., 1903. 
Hadamard, J. La Théorie des Plaques Élastiques Planes. Read Oct. 26, 1901. Transactions of the American Mathematical Society, vol. 3 , No. 4, pp. 401-422; Oct., 1902.

Hancock, H. The Theory of Maxima and Minima of Functions of Several Variables. Read Dec. 27, 1901. University of Cincinnati Bulletin, vol. 2, No. 13, pp. 1-100; 1903.

HAskell, M. W. On a Certain Rational Cubic Transformation in Space. Read (Chicago) Jan. 2, 1902. American Mathematical Monthly, vol. 10, No. 1, pp. 1-3; Jan., 1903.

Generalization of a Fundamental Theorem in the Geometry of the Triangle. Read (Chicago) Jan. 2, 1902. American Mathematical Monthly, vol. 10, No. 2, pp. 30-33; Feb., 1903.

Haskins, C. N. On the Invariants of Differential Forms of Degree Higher than Two. Read Oct. 25, 1902. Transactions of the American Mathematical Society, vol. 4, No. 1, pp. 38-43; Jan., 1903.

Hedrick, E. R. On the Sufficient Conditions in the Calculus of Variations. Read Dec. 28, 1901. Bulletin of the American Mathematical Society, vol. 9, No. 1, pp. 11-24; Oct., 1902.

- On the Characteristics of Differential Equations. Read Dec. 28, 1901 and Feb. 28, 1903. Annals of Mathematics, 2d ser., vol. 4, Nos. 3-4, pp. 121-159; Apr.-July, 1903.

Heffter, L. Ueber Curvenintegrale im $m$-dimensionalen Raum. Read Sept. 3, 1902. Transactions of the American Mathematical Society, vol. 4, No. 2, pp. 142-148; Apr., 1903.

Hook, E. A. Multiple Points on Lissajous's Curves in Two and Three Dimensions. Read Sept. 2, 1902. Annals of Mathematics, 2d ser., vol. 4, No. 2, pp. 67-88; Jan., 1903.

Hudson, R. W. H. T. The Analytic Theory of Displacements. Read Dec. 30, 1902. Bulletin of the American Mathematical Society, vol. 9, No. 6, pp. 308-328; Mar., 1903.

Huntington, E. V. Two Definitions of a Commutative Group by Sets of Independent Postulates. Read Oct. 25, 1902. Transactions of the American Mathematical Socicty, vol. 4, No. 1, pp. 27-30; Jan., 1903.

Definitions of a Field by Sets of Independent Postulates. Read Sept. 2, 1902. Transactions of the American Mathematical Society, vol. 4, No. 1, pp. 31-37; Jan., 1903.

Complete Sets of Postulates for the Theory of Real Quantities. Read Apr. 26 and Dec. 29, 1902. Transactions of the American Mathematical Society, vol. 4, No. 3, pp. 358-370; July, 1903.

JACоBy, H. A Theorem Concerning the Method of Least Squares. Read Dec. 27, 1901. Science, vol. 15, No. 373, pp. 291-292; Feb., 1902.

Kasner, E. The Cogredient and Digredient Theories of Multiple Binary Forms. Read Aug. 20 and Dec. 27, 1901. Transactions of the American Mathematical Society, vol. 4, No. 1, pp. 86-102; Jan. 1903. 
The Generalized Beltrami Problem Concerning Geodesic Representation. Read Dec. 30, 1902. Transactions of the American Mathematical Society, vol. 4, No. 2, pp. 149-152; Apr., 1903.

'The Double-Six Configuration Connected with the Cubic Surface, and a Related Group of Cremona Transformations. Read Feb. 23, 1901. American Journal of Mathematics, vol. 25, No. 2, pp. 107-122; Apr., 1903.

On the Point-Line as Element of Space: A Study of the Corresponding Bilinear Connex. Read Sept. 3, 1902. Transactions of the American Mathematical Society, vol.4, No. 3, pp. 213-233; July, 1903.

The Characterization of Collineations. Read Feb. 28, 1903. Bulletin of the American Mathematical Society, vol. 9, No. 10, pp. 545-546 ; July, 1903.

Keyser, C. J. Concerning the Axiom of Infinity and Mathematical Induction. Read Dec. 29, 1902. Bulletin of the American Mathematical Society, vol. 9, No. 8, pp. 424-434; May, 1903.

Laves, K. Maupertuis's Principle of Least Action for Forces Involving the Coordinates and Their First and Higher Partial Derivatives. Read (Chicago) Apr. 14, 1900. Astronomische Nachrichten, vol. 152, No. 3647, pp. 361-366; June, 1900.

Lehmer, D. N. On the Parametric Representation of the Tetrahedroid Surface. Read (San Francisco) Dec. 20, 1902. American Journal of Mathematics, vol. 25, No. 1, pp. 1-16; Jan., 1903.

Loewy, A. Uber die Reducibilität der Gruppen linearer homogener Substitutionen. Read Sept. 2, 1902. Transactions of the American Mathematical Society, vol. 4, No. 1, pp. 44-64; Jan., 1903.

Ueber die Reducibilität der reellen Gruppen linearer homogener Substitutionen. Read Feb. 28, 1903. Transactions of the American Mathematical Society, vol. 4, No. 2, pp. 171-177; Apr., 1903.

McClintock, E. The Logarithm as a Direct Function. Read Feb. 28, 1903. Bulletin of the American Mathematical Society, vol. 9, No. 9, pp. 467-469; June, 1903.

Macfarlane, A. On the Nabla of Quaternions. Read Feb. 24, 1900. Bulletin of the Philosophical Society of Washington, vol. 14, No. 5, pp. 73-92; July, 1900.

Manning, W. A. The Primitive Groups of Class $2 p$ Which Contain a Substitution of Order $p$ and Degree $2 p$. Read (San Francisco) Apr. 25, 1903. Transactions of the American Mathematical Society, vol. 4, No. 3, pp. 351-357; July, 1903.

MAschke, H. On Superosculating Quadric Surfaces. Read (Chicago) Mar. 29, 1902. Transactions of the American Mathematical Society, vol. 3, No. 4, pp. 482-484; Oct., 1902.

Mirler, G. A. On the Groups of Order $p^{m}$ which contain Operators of Order $p^{m-2}$. Read (Chicago) Jan. 3, 1902. Transactions of the American Mathematical Society, vol. 3, No. 4, pp. 383-387; Oct., 1902. 
On the Holomorph of a Cyclic Group. Read (San Francisco) Dec. 20, 1902. Transactions of the American Mathematical Society, vol. 4, No. 2, pp. 153-160; Apr., 1903.

On a Method for Constructing All the Groups of Order $p^{m}$. Read Dec. 28, 1901. American Journal of Mathematics, vol. 24, No. 4, pp. 395-398; Oct., 1902.

On a Certain Class of Abelian Groups. Read Apr. 28, 1900. Annals of Mathematics, 2d ser., vol. 2, No. 2, pp. 77-80; Jan., 1901.

On a Theorem in Substitutions. Read Oct. 27, 1900. Prace Matematyczno-Fizyczne, vol. 12, No. -, pp. 136-138; 1901.

A Fundamental Theorem with Respect to Transitive Substitution Groups. Read Feb. 28, 1903. Bulletin of the American Mathematical Society, vol. 9, No. 10, pp. 543-544; July, 1903.

A New Proof of the Generalized Wilson's Theorem. Read Dec. 29, 1902. Annals of Mathematics, 2 d ser., vol. 4, No. 4, pp. 188190 ; July, 1903.

Moone, E. H. A Definition of Abstract Groups. Read Apr. 26, 1902. Transactions of the American Mathematical Society, vol. 3, No. 4, pp. 485-492; Oct., 1902.

- On the Foundations of Mathematics. Read Dec. 29, 1902. Bulletin of the American Mathematical Society, vol. 9, No. 8, pp. 402424, May, 1903, and Science, vol. 17, No. 428, pp. 401-416; Mar., 1903.

MoRLey, F. Orthocentric Properties of the Plane $n$-Line. Read Sept. 2, 1902. Transactions of the American Mathematical Society, vol. 4, No. 1, pp. 1-12; Jan., 1903.

- Projective Coordinates. Read Sept. 1, 1903. Transactions of the American Mathematical Society, vol. 4, No. 3, pp. 288-296; July, 1903.

Osgood, W. F. A Jordan Curve of Positive Area. Read Dec. 30, 1902. Transactions of the American Mathematical Society, vol. 4, No. 1, pp. 107-112; Jan., 1903.

On the Transformation of the Boundary in the Case of Conformal Mapping. Read Dec. 30, 1902. Bulletin of the American Mathematical Society, vol. 9, No. 5, pp. 233-235; Feb., 1903.

The Integral as the Limit of a Sum, and a Theorem of Duhamel. Read Feb. 28, 1903. Annals of Mathematics, 2d ser., vol. 4, No. 4, pp. 161-178; July, 1903.

Roe, E. D., JR. Note on Symmetric Functions. Read Aug. 20, 1901. American Journal of Mathematics, vol. 25, No. 1, pp. 97-106; Jan., 1903.

Scotr, C. A. On the Circuits of Plane Curves. Read Apr. 26, 1902. Transactions of the American Mathematical Society, vol. 3, No. 4, pp. 388-398; Oct., 1902.

Note on the Real Inflexions of Plane Curves. Read Dec. 28, 1901. Transactions of the American Mathematical Society, vol. 3, No. 4, pp. 399-400; Oct., 1902. 
SHAw, J. B. Theory of Linear Associative Algebra. Read Sept. 2, 1902. Transactions of the American Mathematical Society, vol. 4, No. 3, pp. 251-287; July, 1903.

Skinner, E. B. On Ternary Monomial Substitution Groups of Finite Order with Determinant \pm 1 . Read (Chicago) Dec. 28, 1900. American Journal of Mathematics, vol. 25, No. 1, pp. 17-58; Jan., 1903.

SNyder, V. On the Quintic Scroll Having Three Double Conics. Read Oct. 25, 1902. Bulletin of the American Mathematical Society, vol. 9, No. 5, pp. 236-242; Feb., 1903.

On the Forms of Unicursal Sextic Scrolls. Read Aug. 20 and Dec. 27, 1901. American Journal of Mathematics, vol. 25, No. 1, pp. 59-84; Jan., 1903.

On the Forms of Sextic Scrolls of Genus Greater than One. Read Sept. 3, 1902. American Journal of Mathematics, vol. 25, No. 3, pp. 261-268; July, 1903.

Stecker, H. F. Non-Euclidean Properties of Plane Cubics and of Their First and Second Polars. Read Aug. 20, 1901. American Journal of Mathematics, vol. 24, No. 4, pp. 399-408; Oct., 1902.

TAYLOR, W. E. On the Product of an Alternant by a Symmetric Function. Read Dec. 29, 1902. American Mathematical Monthly, vol. 10, No. 5, pp. 120-130; May, 1903.

VAN VIECK, E. B. On an Extension of the 1894 Memoir of Stieltjes. Read Feb. 28, 1903. Transactions of the American Mathematical Society, vol. 4, No. 3, pp. 297-332; July, 1903.

Westuund, J. On the Class number of the Cyclotomic Number Field $k\left(e^{2 \pi^{i} / p^{n}}\right)$. Read Sept. 2, 1902. Transactions of the American Mathematical Society, vol 4, No. 2, pp. 201-212; Apr., 1903.

WhITE, H. S. On Twisted Cubic Curves that have a Directrix. Read Sept. 3, 1902. Transactions of the American Mathematical Society, vol. 4, No. 2, pp. 134-141; Apr., 1903.

- Twisted Quartic Curves of the First Species and Certain Covariant Quartics. Read (Chicago) Dec. 30, 1897. Annals of Mathematics, 2 d ser., vol. 4, No. 3, pp. 116-120; Apr., 1903.

Wilczynski, E. J. Covariants of Systems of Linear Differential Equations and Applications to the Theory of Ruled Surfaces. Read Feb. 22, 1902 and (San Francisco) May 3, 1902. Transactions of the American Mathematical Society, vol. 3, No. 4, pp. 423-450; Oct., 1902.

- On a Certain Congruence Associated with a Given Ruled Surface. Read (San Francisco) Dec. 20, 1902. Transactions of the American Mathematical Society, vol. 4, No. 2, pp. 185-200; Apr., 1903.

Wilson, E. B. The Synthetic Treatment of Conics at the Present Time. Read Dec. 29, 1902. Bulletin of the American Mathematical Society, vol. 9, No. 5, pp. 248-254; Feb., 1903.

Young, J. W. On a Certain Group of Isomorphisms. Read Feb. 22, 1902. American Journal of Mathematics, vol. 25, No. 2, pp. 206212 ; Apr., 1903. 
